\title{
DETERMINATION OF DIADENOSINE TETRAPHOSPHATE IN BIOLOGICAL MATERIAL BY HIGH PRESSURE LIQUID CHROMATOGRAPHY1)
}

\author{
by \\ PAUL PLESNER \\ Department of Molecular Biology, Section of Cell Biology, \\ University of Odense. Campusvej 55. DK-5230 Odense M \\ and \\ MARTIN OTTESEN \\ Department of Chemistry, Carlsberg Laboratory, \\ Gamle Carlsbergvej 10, DK-2500 Copenhagen Valby
}

Keywords: Diadenosine tetraphosphate, high pressure liquid chromatography, alkaline phosphatase

A method for determination of diadenosine tetraphosphate. $\mathrm{Ap}_{4} \mathrm{~A}$, by high pressure liquid chromatography has been developed. The free nucleotides were extracted from biological material with $10 \%$ trichloroacetic acid. which subsequently was removed with n-trioctylamine dissolved in freon; the aquous phase containing the nucleotides was lyophilized. The lyophilized material was dissolved in $0.1 \mathrm{~m}-\mathrm{NaHCO}_{3}$, digested with alkaline phosphatase, injected into a strong anion exchange column without adjustment of $\mathrm{pH}$ and chromatographed isocratically with a $\mathrm{KH}_{2} \mathrm{PO}_{4}-\mathrm{KCl}$ buffer at $\mathrm{pH} 4$.3. The enzymatic digestion of the cellular nucleoside mono-, di-. and triphosphates was followed and found to be completed in two hours, while Ap $4 \mathrm{~A}$ was observed not to be cleaved during this period. Amounts as small as 5-10 picomoles of $\mathrm{Ap}_{4} \mathrm{~A}$ were determined quantitatively by the method described.

1) Some of the results of the present study have been presented at the symposium: "Regulation of Macromolecular Synthesis by Low Molecular Weight Mediators" in Hamburg, May 1979 (G. KoCH \& D. RICHTER) (13). 


\section{INTRODUCTION}

Diadenosine tetraphosphate $\left(\mathrm{Ap}_{4} \mathrm{~A}\right)^{2)}$, was found by ZAMECNIK et al. to be formed in vitro in the reverse reaction of amino acid activation (19), and determination of $\mathrm{Ap}_{4} \mathrm{~A}$ in these systems could be accomplished by thin layer ion exchange chromatography on PEI cellulose plates (TLC), because none of the nucleotides used interfered with the analysis. The in vitro reaction mixture was first treated with alkaline phosphatase to remove all free 5' phosphate groups on the nucleotides. The digest was then subjected to TLC, and $\mathrm{Ap}_{4} \mathrm{~A}$ was eluted from the plates. The amount of $\mathrm{Ap}_{4} \mathrm{~A}$ was measured by cleavage with snake venom phosphodiesterase to AMP and ATP, the ATP thus formed being measured with luciferase by using a scintillation counter (M. L. STEPHENSON, unpublished). RAPAPORT and ZAMECNIK introduced a method for separating radioactively labeled $\mathrm{Ap}_{4} \mathrm{~A}$ by twostep DEAE Sephadex-DEAE cellulose chromatography and quantitated $\mathrm{Ap}_{4} \mathrm{~A}$ by measurement of radioactivity; based on the results obtained with this method, they suggested that $\mathrm{Ap}_{4} \mathrm{~A}$ functions as a pleiotypic activator of macromolecular synthesis in the cell (15). This suggestion has been further supported by GRUMmT, who found that $\mathrm{Ap}_{4} \mathrm{~A}$ has a stimulatory effect on the DNA synthesis in permeabilized baby hamster kidney cells (3), and from measurements by PLESNER et al. of the variations in the in vivo content of $\mathrm{Ap}_{4} \mathrm{~A}$ in several proliferating cellular systems (12). Recently Grumm and collaborators have found that $\mathrm{Ap}_{4} \mathrm{~A}$ binds specifically to the $57 \mathrm{k}$ subunit of DNA polymerase $\alpha$ (4). They assume that this binding of $\mathrm{Ap}_{4} \mathrm{~A}$ to the polymerase is responsible for the biological effect of $\mathrm{Ap}_{4} \mathrm{~A}$, since a structural analog of $\mathrm{Ap}_{4} \mathrm{~A}$ both inhibits this binding as well as the replication of DNA and cell proliferation (5).

In the present paper a simplified method is described which enables the determination of $\mathrm{Ap}_{4} \mathrm{~A}$ in amounts as small as $5-10$ pmoles in cultures of Tetrahymena pyriformis.

2) The following abbreviations will be used: $\mathrm{Ap}_{4} \mathrm{~A}$ : Diadenosine 5', 5"'-P1, P4-tetraphosphate, HPCL: High pressure liquid chromatography, TLC: Thin layer chromatography.

\section{MATERIALS}

Tetrahymena pyriformis GL cells were grown axenically in a medium consisting of proteose peptone, yeast extract, and salts listed in Reference (9); the composition of the starvation medium ( 5 mm-Tris- $\mathrm{HCl}, \mathrm{pH} 7.3$ at $20^{\circ} \mathrm{C}, 47$ $\mathrm{mm}-\mathrm{NaCl}, 1 \mathrm{~mm}-\mathrm{MgSO}_{4}$ ) and the technique for growing the cells are described elsewhere (10). The cells were transferred to starvation medium by centrifugation at $275 \mathrm{~g}(\max )$ for $3 \mathrm{~min}$ and resuspension twice in an equal volume of starvation medium.

Buffers were prepared from reagent grade $\mathrm{KH}_{2} \mathrm{PO}_{4}$ and $\mathrm{KCl}$ (E. Merck, Darmstadt) in glass distilled water and filtered through Millipore filters HA, pore size $0.45 \mu \mathrm{m}$ (Millipore, Bedford, Massachusetts).

Diadenosine tetraphosphate was a gift from Dr. E. RAPAPORT, Boston, USA. The preparation was found to be $97 \%$ pure by chromatography as described in Section 3.3. A molar absorbance coefficient of $24.3 \times 10^{3}$ (14) was used for estimating the concentration of stock solutions. Tri-n-octylamine (referred to as trioctylamine in the following) and nucleotides were obtained from Sigma Chemical company, St. Louis, Missouri). Freon 113 was from DuPont (Newark, Delaware). Alkaline phosphatase (E.C. 3.1.3.1.) grade BAPF (from E. coli) was purchased from Worthington, Freehold, New Jersey.

\section{METHODS}

\subsection{Sampling of cells and preparation of extracts}

Samples of one $\mathrm{ml}$ were removed from the cultures with precision wide-bore syringes and immediately mixed with one $\mathrm{ml}$ ice-cold $20 \%$ trichloroacetic acid without prior centrifugation. The mixture was cooled to $0^{\circ} \mathrm{C}$, kept in an icebath for $30 \mathrm{~min}$ and centrifuged at about $1200 \mathrm{~g}$ for $10 \mathrm{~min}$ at $0-4{ }^{\circ} \mathrm{C}$ in a swing-out head. The precipitate was stored at $-20^{\circ} \mathrm{C}$ and later used for determination of protein. The trichloroacetic acid was removed from the supernatant as described by CHEN et al. (1); an equal volume of $0.5 \mathrm{M}$-trioctylamine in freon (freshly prepared) was mixed vigorously with the trichloroacetic acid extract for $3 \mathrm{~min}$. The phases were then separated by centrifugation at about $3000 \mathrm{~g}$ at 0 
$4{ }^{\circ} \mathrm{C}$ for $5 \mathrm{~min}$ and the upper phase removed with a constriction pipette. The de-acidified extract was frozen at $-80^{\circ} \mathrm{C}$ in inclined plastic test tubes. The tubes were stoppered with perforated plastic caps, lyophilized and stored over silica gel at $-80^{\circ} \mathrm{C}$ until analyzed.

\subsection{Enzyme digestion}

An incubation mixture containing $5 \mu \mathrm{l}$ alkaline phosphatase (approximately 0.5 units) per $\mathrm{ml}$ in $0.1 \mathrm{M}-\mathrm{NaHCO}_{3}, 1 \mathrm{~mm}-\mathrm{MgCl}_{2}$ was prepared freshly in each experiment. $200 \mu \mathrm{l}$ of the enzyme incubation mixture was added to the lyophilized extract and left at room temperature for two hours to complete the enzymatic cleavage of nucleotides. The samples were then cooled to $4^{\circ} \mathrm{C}$ and chromatographed.

\subsection{High pressure liquid chromatography}

A Waters High Pressure Liquid Chromatograph (Waters Associates, Milford, Massachusetts) with a double beam UV detector equipped with a $254 \mathrm{~nm}$ filter was used. Peak areas were integrated with a Hewlett-Packard 3380A integrator or a Waters M730 Data Module.

Prepacked strong anion exchange columns consisting of a silica base material bonded to a quaternary ammonium ion through a $\mathrm{Si}-\mathrm{O}-\mathrm{Si}$ bond were used. The columns, $25 \mathrm{~cm} \times 4.6$ mm I.D. in stainless steel tubing, were supplied by Whatmann Inc. (Clifton, New Jersey), catalog listing: Partisil PXS 10/25-SAX. A guard column packed with Corasil AX (Waters Associates, Milford, Massachusetts) was used.

The chromatographic separation followed the principles described by Phyllis Brown and coworkers $(1,6)$. Isocratic elution was used throughout the present study. The eluent was $0.25 \mathrm{M}-\mathrm{KH}_{2} \mathrm{PO}_{4}, 0.5 \mathrm{~m}-\mathrm{KCl}$ at $\mathrm{pH} 4.3$. The flow rate was 1.0 or $1.5 \mathrm{ml}$ per minute. The eluent was degassed prior to use and chromatography was performed at room temperature. The $200 \mu \mathrm{l}$ sample of enzyme digest described in Section 3.2 was injected directly without prior $\mathrm{pH}$ adjustment or enzyme inactivation. Reproducible results were obtained only when the sample was injected on a cushion of an equal volume of 0.1 $\mathrm{M}-\mathrm{NaHCO}_{3}$ as described by Rivier (16).

\subsection{Protein determination}

Protein was determined as described by Lowry et al. (7) using bovine serum albumin as standard.

\section{RESULTS}

In the experiment, the results of which are shown in Figure 1, identical amounts of $\mathrm{Ap}_{4} \mathrm{~A}$ stock solution were adjusted to different $\mathrm{pH}$ values as follows: A) $\mathrm{pH} 1.5$ by mixing with elution buffer adjusted with $\mathrm{H}_{3} \mathrm{PO}_{4}, \mathrm{~B}$ ) $\mathrm{pH} 4.3$ with elution buffer, C) elution buffer adjusted to $\mathrm{pH} 5.1$ with $\mathrm{KOH}$, and $\mathrm{D}) \mathrm{pH} 9.0$ in $0.1 \mathrm{M}$ $\mathrm{NaHCO}_{3}$. The final volumes of $\mathrm{A}-\mathrm{D}$ were identical. $200 \mu \mathrm{l}$ samples of the various solutions were chromatographed using $0.25 \mathrm{~m}$-phosphate, $0.5 \mathrm{M}-\mathrm{KCl}$ buffer of $\mathrm{pH} 4.3$ as eluent. As seen in the figure, the retention times and shapes of the eluted peaks were strongly dependent on the initial $\mathrm{pH}$ of the injected sample. All peaks were asymmetrical and the most narrow was detected when the sample was injected with $\mathrm{NaHCO}_{3}$ at $\mathrm{pH}$ 9.0. Since narrow band width facilitates automatic integration, $\mathrm{NaHCO}_{3}$ at $\mathrm{pH} 9$ was used for injection of the samples in the standard procedure.

In order to determine the optimal time of incubation with alkaline phosphatase the time course of the enzymatic splitting of $5^{\prime}$ free phosphate ester groups in nucleotides was followed. In the experiment (Figure 2) a reaction mixture of $2 \mathrm{ml}$ was used for the digestion of extract from $10 \mathrm{ml}$ of cell culture with a negligible content of $\mathrm{Ap}_{4} \mathrm{~A}$. The culture contained $4 \times 10^{5}$ cells per $\mathrm{ml}$ with a protein content of $0.6 \mathrm{mg}$ protein per $\mathrm{ml}$. The extract was prepared as described in Section 3.1. and 27 nanomoles of $\mathrm{Ap}_{4} \mathrm{~A}$ were added as internal marker after the first sample had been removed for chromatography. $200 \mu l$ samples were then removed at intervals for chromatography. Figure $2 \mathrm{~A}$ shows a chromatogram before the internal marker was added; Figure $2 \mathrm{~B}$ shows the result immediately after addition of the marker. A series of chromatograms obtained during the reaction showed that ATP (the last peak in Figure $2 \mathrm{~A}$ and $2 \mathrm{~B}$ ) was completely absent after $140 \mathrm{~min}$ when the chromatogram had an appearance like Figure 2C. In parallel experi- 


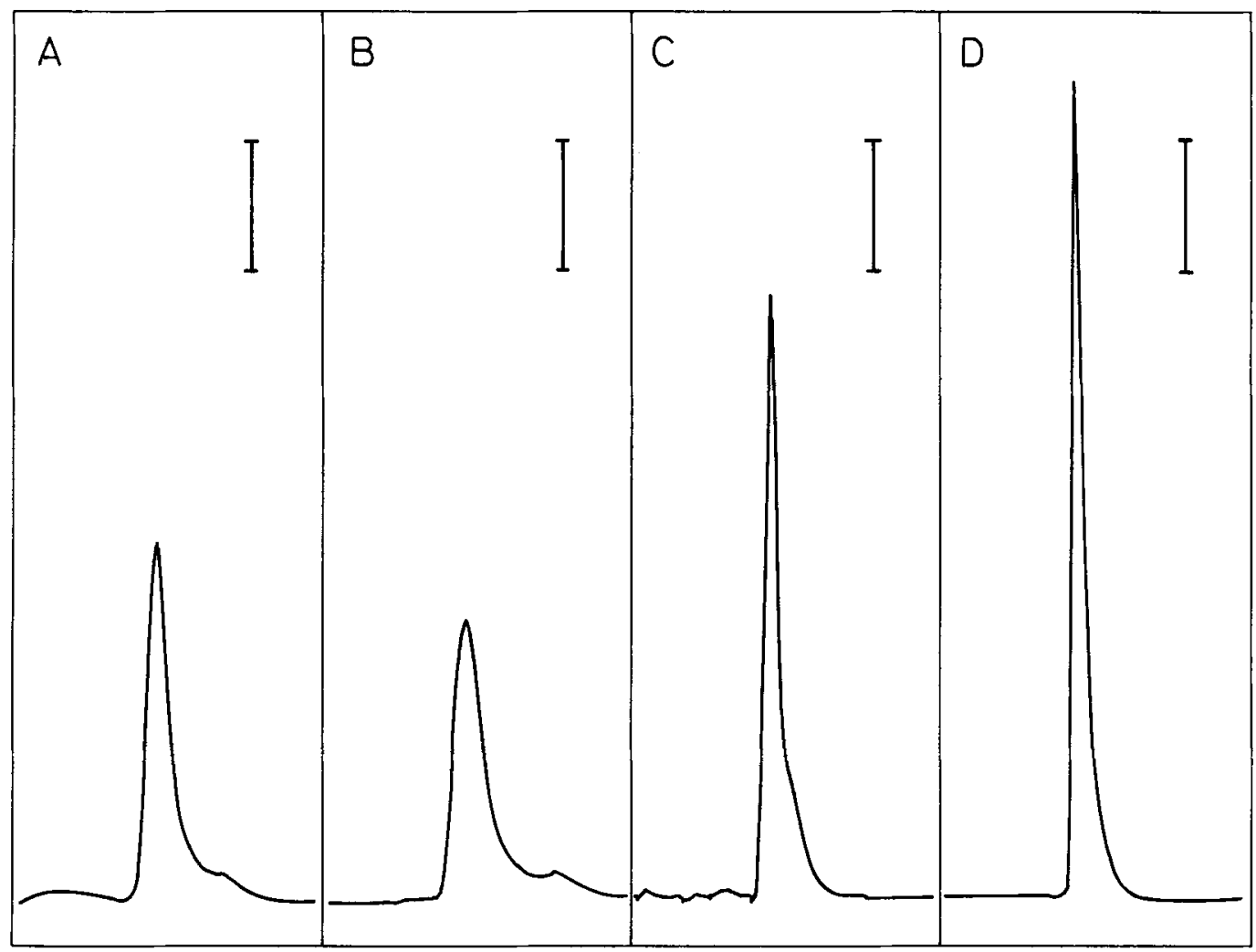

Figure 1. Chromatograms of $\mathrm{Ap}_{4} \mathrm{~A}$ at different $\mathrm{pH}$ values. In each chromatogram $25 \mu \mathrm{l}$ of $\mathrm{Ap}_{4} \mathrm{~A}$ stock solution, containing 55 nmoles of $\mathrm{Ap}_{4} \mathrm{~A}$ was mixed with an equal volume of solvent to adjust the $\mathrm{pH}$ of the $\mathrm{Ap}_{4} \mathrm{~A}$ solution injected.

A: $\mathrm{pH}$ of injected sample: 1.5 (mixed with elution buffer adjusted with $\mathrm{H}_{3} \mathrm{PO}_{4}$ ). B: $\mathrm{pH}$ of injected sample: 4.3 (adjusted with elution buffer). C: $\mathrm{pH}$ of injected sample: 5.1 (adjusted with elution buffer and KOH). D: $\mathrm{pH}$ of injected sample: 9 (in $0.1 \mathrm{M}-\mathrm{NaHCO}_{3}$ ). All samples were eluted at $\mathrm{pH} \mathrm{4.3.} \mathrm{Abscissae:} \mathrm{Retention} \mathrm{times.}$ Ordinates: Absorbance at $254 \mathrm{~nm}$. The retention times of Ap 4 A were A: $12.7 \mathrm{~min}, \mathrm{~B}: 12.1 \mathrm{~min}, \mathrm{C}: 11.6 \mathrm{~min}, \mathrm{D}$ : $10.4 \mathrm{~min}$. The flow rate was $1 \mathrm{ml}$ per $\mathrm{min}$. The bar indicates 0.01 absorbance unit in all frames.

ments it was shown that CTP and TTP cochromatograph with $\mathrm{Ap}_{4} \mathrm{~A}$ in this system, and consequently the decrease in area and the difference in the shape of the $\mathrm{Ap}_{4} \mathrm{~A}$ peak might well be caused by splitting of 5' pyrimidine nucleoside triphosphates by the phosphatase. The recovery of $\mathrm{Ap}_{4} \mathrm{~A}$ as estimated by comparison with the area of an external standard was about $90 \%$ of the theoretical value. Consequently, the experiment confirms that $\mathrm{Ap}_{4} \mathrm{~A}$ is stable during 220 min incubation with alkaline phosphatase, and it is seen that a characteristic " $\mathrm{Ap}_{4} \mathrm{~A}$ shape appears as the reaction proceeds. In contrast to the experiment just described where cells were harvested shortly after transfer to starvation medium in order to obtain a chromatogram with optimal resolution of the peaks, material from cells in nutrient medium often show chromatograms with only one major peak. Tangent peaks are easily quantitated by comparison with a chromatogram of an identical sample to which a known amount of $\mathrm{Ap}_{4} \mathrm{~A}$ has been added (Figure 3). Co-chromatography of the unknown with the added $\mathrm{Ap}_{4} \mathrm{~A}$ is also ascertained by using this method of quantitation

Figure 4 shows two chromatograms of 


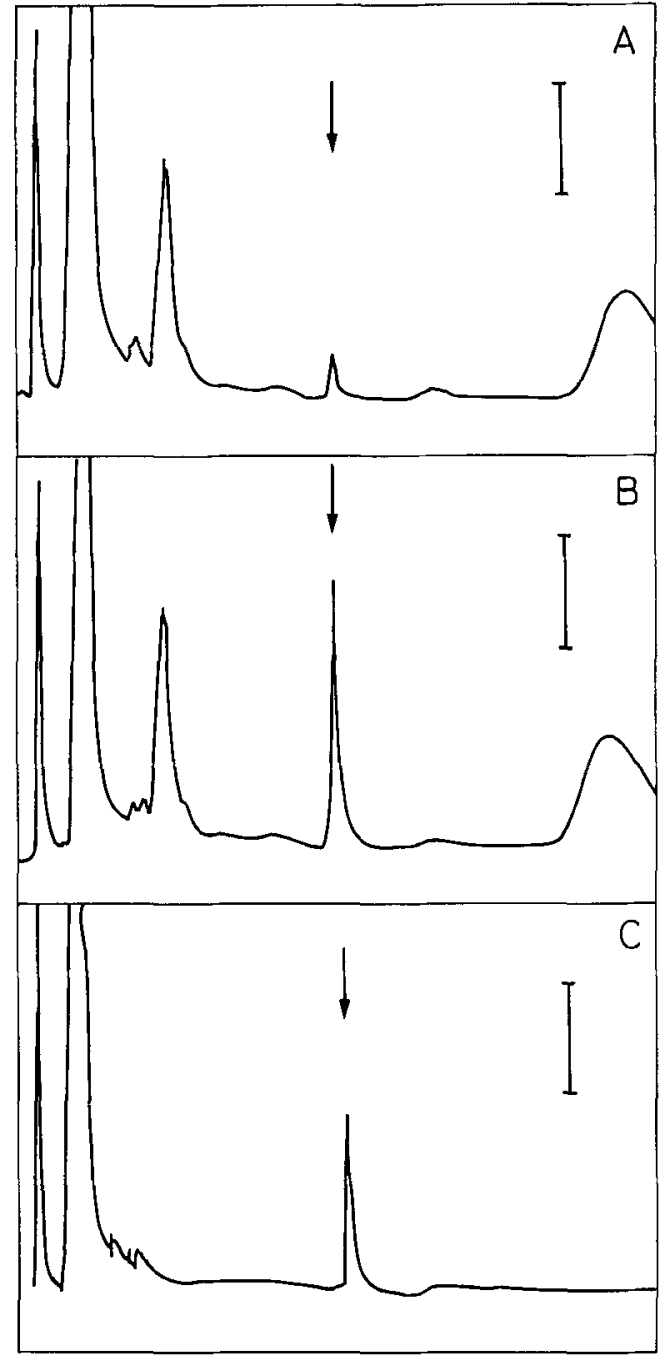

Figure 2. Enzymatic hydrolysis of a nucleotide extract by alkaline phosphatase. Chromatograms of samples from a reaction mixture containing extract of $10 \mathrm{ml}$ cell culture dissolved in $2 \mathrm{ml}$ of $0.1 \mathrm{M}$ $\mathrm{NaHCO}_{3}, 1 \mathrm{~mm} \cdot \mathrm{MgCl}_{2}$.

A: Chromatogram of a sample before the addition of alkaline phosphatase and internal $\mathrm{Ap}_{4} \mathrm{~A}$ marker. B: Chromatogram of a sample after the addition of 27 nmoles of $\mathrm{Ap}_{4} \mathrm{~A}$ to the reaction mixture. $\mathrm{C}$ : Chromatogram of a sample $220 \mathrm{~min}$ after $8 \mu \mathrm{l}$ of alkaline phosphatase was added. $200 \mu \mathrm{l}$ were used for each chromatogram. The chromatograms in $\mathrm{B}$ and $\mathrm{C}$ represent the first and last value in Table $\mathrm{I}$, respectively. Abscissae and ordinates as in Figure 1. The retention times of the $\mathrm{Ap}_{4} \mathrm{~A}$ peak were all about $12 \mathrm{~min}$. The flow rate was $0.1 \mathrm{ml}$ per min. The bar indicates 0.08 absorbance unit.
Table I

The time course of enzymatic digestion of a nucleotide extract

\begin{tabular}{cc}
$\begin{array}{c}\text { Minutes after the } \\
\text { addition of enzyme }\end{array}$ & $\begin{array}{c}\text { Absorbance expressed } \\
\text { as nanomoles of } \mathrm{Ap}_{4} \mathrm{~A}\end{array}$ \\
\hline 6 & 4.05 \\
45 & 3.39 \\
110 & 2.90 \\
140 & 2.85 \\
165 & 2.65 \\
192 & 2.82 \\
220 & 2.75 \\
\hline
\end{tabular}

The extract was prepared and digested as described in Section 3.1 and 3.2 , respectively. The results are from the same experiment as the chromatograms shown in Figure 2. For each time-point a sample was chromatographed and the absorbance of the band that chromatographs with the retention time of $\mathrm{Ap}_{4} \mathrm{~A}$ was expressed as nanomoles of $\mathrm{Ap}_{4} \mathrm{~A}$.

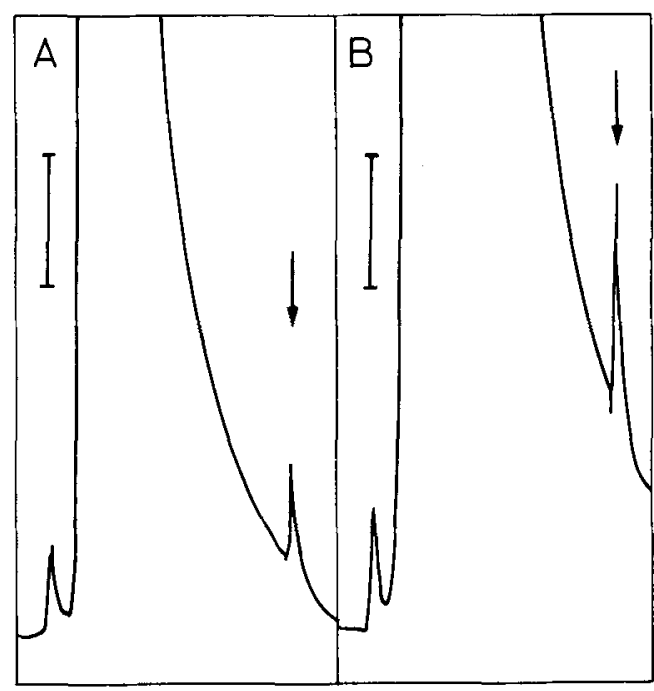

Figure 3. The quantitation of $\mathrm{Ap}_{4} \mathrm{~A}$ in a chromatogram. Two $200 \mu l$ enzyme digests were mixed.

A: HPLC of one half of the mixture. The area of the $\mathrm{Ap}_{4} \mathrm{~A}$ peak (shown by the arrow) was $78.9 \times 10^{3}$ area units. B: Same as A, but with the addition of 150 picomoles of $\mathrm{Ap}_{4} \mathrm{~A}$. The area of the peak was $143.5 \times 10^{3}$ units. From this the content of $\mathrm{Ap}_{4} \mathrm{~A}$ in A was calculated to be 183 picomoles.

$$
\left(\frac{78.9}{143.5-78.9} \times 150\right)
$$

Abscissae and ordinates as in Figure 1. The retention times of the $\mathrm{Ap}_{4} \mathrm{~A}$ peaks were about $9 \mathrm{~min}$, the flow rate was $1.5 \mathrm{ml}$ per $\mathrm{min}$. The bar indicates 0.04 absorbance unit. 


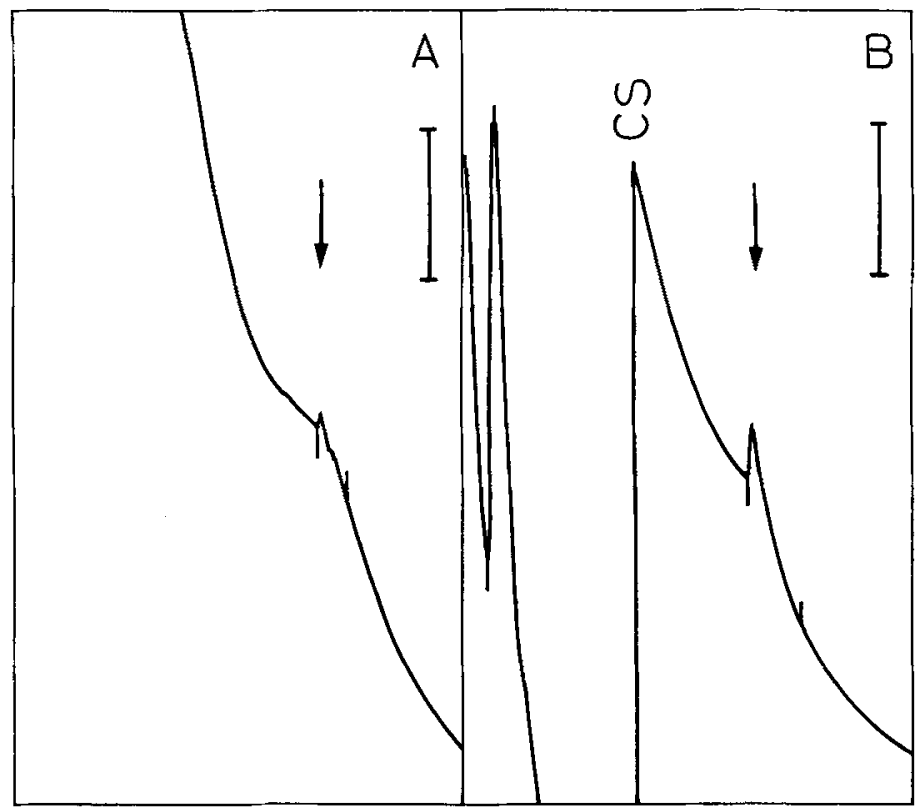

Figure 4. Chromatograms of extracts from Tetrahymena pyriformis under starvation conditions.

A: Cells harvested $5 \mathrm{~min}$ after transfer from nutrient to starvation medium. The content of $\mathrm{Ap}_{4} \mathrm{~A}$ was 7 pmoles per $\mathrm{mg}$ protein. $B$ : Cells harvested $60 \mathrm{~min}$ after transfer from nutrient 10 starvation medium. The content of $\mathrm{Ap}_{4} \mathrm{~A}$ was 27 pmoles per mg protein. Arrows show the Ap $4 \mathrm{~A}$ peaks. Abscissae and ordinates as in Figure 1. The retention times of the $\mathrm{Ap}_{4} \mathrm{~A}$ peaks were about $9 \mathrm{~min}$, the flow rate was $1.5 \mathrm{ml}$ per min. The bar indicates 0.001 absorbance unit.

extracts of Tetrahymena pyriformis cells under starvation conditions. The chromatograms have been selected from a series of determinations to indicate the lower limit of detection. The figure shows that the lowest content measured was 7 pmoles per mg protein. After 60 minutes in the starvation medium the content of $\mathrm{Ap}_{4} \mathrm{~A}$ had increased to 27 pmoles per mg protein.

Since rich media occasionally contain components which co-chromatograph with $\mathrm{Ap}_{4} \mathrm{~A}$ in the present method, it is necessary to make a blank run to ascertain the absence of interfering substance.

\section{DISCUSSION}

In the present communication a method for determination of diadenosine tetraphosphate, $\mathrm{Ap}_{4} \mathrm{~A}$, in a biological material is described. $\mathrm{Ap}_{4} \mathrm{~A}$ was identified by co-chromatography with a known standard (Figure 3 ) and by its resistance to alkaline phosphatase (Figures 2 and 3). Like in the present paper, the compound assumed to be $\mathrm{Ap}_{4} \mathrm{~A}$ was previously observed to be eluted close to UTP, TTP. and CTP by chromatography when a gradient system described by HARTwICK and Brown was used $(6,12)$. Diguanosine tetraphosphate (2) is found in some cells and is probably resistant to alkaline phosphatase. It is, however, separated from $\mathrm{Ap}_{4} \mathrm{~A}$ due to its longer retention time both in isocratic and gradient systems (unpublished results). NAD and nucleotides that enzymatically would be hydrolyzed to NAD cause no interference in the system used here, since the retention time of NAD is less than $2 / 3$ of that of $\mathrm{Ap}_{4} \mathrm{~A}$.

In some of the chromatograms shown in the present paper (e.g. Figure 3) $\mathrm{Ap}_{4} \mathrm{~A}$ appears as a so-called tangent peak, or rider, at the foot of a peak more than thousand times larger in area. The integrators used recognize, and quantitate such tangent peaks most easily when they are as 
narrow as in Figure 3. The observations on the shape of the $\mathrm{Ap}_{4} \mathrm{~A}$ peak at different $\mathrm{pH}$ values taken together with the fact that $\mathrm{Ap}_{4} \mathrm{~A}$ is extremely stable at an alkaline $\mathrm{pH}$ (no hydrolysis in $0.24 \mathrm{M}$ - $\mathrm{LiOH}$ at $30^{\circ} \mathrm{C}$ for one hour) (14), indicates that the present method of analysis is preferable, also because of its simplicity.

The wide range of $\mathrm{Ap}_{4} \mathrm{~A}$ content in living organisms which exceeds the range of the ATP content $(11,17,18)$ supports the hypothesis of RAPAPORT and $\mathrm{Z}_{A M E C N I K}$ that $\mathrm{Ap}_{4} \mathrm{~A}$ may act as a positive metabolic activator. Turnover studies are needed to elucidate this question further and the use of the HPLC method should make such studies possible, because determinations of specific radioactivity values based on quantitation by light absorbance measurements have been made feasible.

\section{ACKNOWLEDGEMENTS}

This work was initiated during a visit in 1978 by one of the authors (PP) to the Huntington Laboratories of Harvard University at the Massachusetts General Hospital, Boston, USA, and he wants to thank Dr. P. C. ZAMECNIK and Dr. M. L. STEPhenson for their generous and kind help during his stay there. We thank Dr. F. Grummt, Martinsried, W. Germany, for preprints. We are thankful to Dr. KarSTEN KRISTIANSEN and Ms. ANNA KRÜGER for providing cellular material, to Dr. S. E. GodTFREDSEN for critically reading the manuscript, and to Ms. Ulla Pedersen and Kethe Jørgensen for secretarial help. The work has received support from the Danish Medical Research Council and the Danish Cancer Society.

\section{REFERENCES}

1. Chen, S., P. R. Brown \& D. M. Rosie: Extraction procedures for use prior to HPLC nucleotide analysis using microparticle chemically bonded packings. J. Chrom. Sci. 15, $218-$ 221 (1977)

2. Finamore,F. J. \& A. H. Warner: The occurrence of $\mathrm{P}$ ', $\mathrm{P}^{4}$-diguanosine 5'-tetraphosphate in brine shrimp eggs. J. Biol. Chem. 238, 344-348 (1963)

3. Grummt, F.: Diadenosine 5', 5"'-PI, P4-tetraphosphate triggers initiation of in vitro DNA replication in baby hamster kidney cells. Proc. Natl. Acad. Sci. USA 75, 371-375 (1978)

4. Grummt, F., G. Waltl, H.-M. Jantzen, K. Hamprecht, U. Huebscher \& C. C. Kuenzle: Diadenosine 5', 5"'-PI, P4-tetraphosphate $\left(\mathrm{Ap}_{4} \mathrm{~A}\right)$, a ligand of the $57 \mathrm{k}$ subunit of DNA polymerase $\alpha$. Proc. Natl. Acad. Sci. USA, in the press.

5. Grummt, F. G. Waltl, H.-M. Jantzen, K. Hamprecht, U. Huebscher \& C. C. Kuenzle: Diadenosine tetraphosphate - a ligand of DNA polymerase $\alpha$ and trigger of replication. In: »Regulation of Macromolecular Synthesis by Low Molecular Weight Mediators«. (G. Koch \& D. Richter, eds.) Academic Press, N.Y., 209-221 (1979)

6. Hartwick, R. A. \& P. R. BRown: The performance of microparticle chemically-bonded anion-exchange resins in the analysis of nucleotides. J. Chrom. 112, 651-662 (1975)

7. Lowry, O. H., N. J. Rosebrough, A. L. Farr \& R. J. RANDALL: Protein measurement with the Folin phenol reagent. J. Biol. Chem. 193, 265$275(1951)$

8. Кнум, J. X.: An analytical system for rapid separation of tissue nucleotides at low pressures on conventional anion exchanges. Clin. Chem. 21, 1245-1252 (1975)

9. Kristiansen, K., B. Hartmann, P. Plesner \& A. KRÜGER: Conservation of active ribosomes in acetone-treated cells of Tetrahymena pyriformis. Eur. J. Biochem. 83, 389-394 (1978)

10. Kristiansen, K., P. Plessner \& A. Krüger: Phosphorylation in vivo of ribosomes in Tetrahymena pyriformis. Eur. J. Biochem. 83, 395403 (1978)

11. Plesner, P.: Nucleotide metabolism during synchronized cell division in Tetrahymena pyriformis. Compt. Rend. Trav. Lab. Carlsberg 34. 1-76 (1964)

12. Plesner, P., M. L. Stephenson, P. L. Zamecnik \& N. R. L. Bucher: Diadenosine tetraphosphate $\left(\mathrm{Ap}_{4} \mathrm{~A}\right)$, an activator of gene function. In: $n$ Specific Eukaryotic Genes« (J. Engberg, V. Leick \& H. Klenow, eds.) pp. 383-393, Munksgaard, Copenhagen (1979)

13. Plesner, P. \& K. Kristiansen: Relation of protein synthesis to the content of adenosine polyphosphates. In: „Regulation of Macromolecular Synthesis by Low Molecular Weight Mediators« (G. Koch \& D. Richter, eds.). Academic Press, N.Y., 233-248 (1979)

14. Randerath, K., C. M. Janeway, M. L. StePhenson \& P. C. ZameCniK:Isolation and characterization of dinucleoside tetra- and tri- 
phosphates formed in the presence of lysyl-s RNA synthetase. Biochem. Biophys. Res. Comm. 24, 98-105 (1966)

15. RaPAPORT, E. \& P. C. ZameCNiK: Presence of diadenosine 5', 5"'-PI, $\mathrm{P}^{4}$-tetraphosphate $\left(\mathrm{Ap}_{4} \mathrm{~A}\right)$ in mammalian cells in levels varying widely with proliferative activity of the tissue: A possible positive "pleiotypic activator $\ll$. Proc. Natl. Acad. Sci. USA 73, 3984-3988 (1976)

16. Rivier, J. E.: Use of trialkyl ammonium phosphate (TAAP) buffers in reverse phase HPLC for high resolution and high recovery of peptides and proteins. J. Liquid. Chrom. 1.343366 (1978)

17. Scherbaum, O., S. Chou, K. H. Seraydarian \&
J. E. Byfield: The effect of temperature shifts on the intracellular level of nucleoside triphosphates in Tetrahymena pyriformis. Can. J. Microbiol. 8, 753-760 (1962)

18. Swedes, J. S., R. J. Sedo \& D. E. Atkinson: Relation of growth and protein synthesis to the adenylate energy charge in an adenine requiring mutant of Escherichia coli. J. Biol. Chem. 250, 6930-6934 (1975)

19. Zamecnik, P. C., M. L. Stephenson, C. M. JANEWAY \& K. RaNDERATH: Enzymatic synthesis of diadenosine tetraphosphate and diadenosine triphosphate with a purified lysyl-s RNA synthetase. Biochem. Biophys. Res. Comm. 24, 91-97 (1966) 